\title{
Article \\ Financial Reporting as a Source of Innovation-Relevant Competitive Intelligence
}

\author{
Vincent $\mathrm{O}^{\prime}$ Connell ${ }^{1,2, *}$, Naser AbuGhazaleh ${ }^{1}$ and Garvan Whelan ${ }^{1}$ (D) \\ 1 Department of Accounting and MIS, Gulf University for Science and Technology, P.O. Box 7207, \\ Hawally 32093, Kuwait; Abughazaleh.n@gust.edu.kw (N.A.); Whelan.G@gust.edu.kw (G.W.) \\ 2 Cork University Business School, University College Cork, Cork T12 K8AF, Ireland \\ * Correspondence: oconnell.v@gust.edu.kw or vincent.oconnell@ucc.ie
}

check for

updates

Citation: O'Connell, V;

AbuGhazaleh, N.; Whelan, G

Financial Reporting as a Source of

Innovation-Relevant Competitive

Intelligence. J. Open Innov. Technol.

Mark. Complex. 2021, 7, 117. https://

doi.org/10.3390/joitmc7020117

Received: 30 December 2020

Accepted: 15 April 2021

Published: 22 April 2021

Publisher's Note: MDPI stays neutral with regard to jurisdictional claims in published maps and institutional affiliations.

Copyright: (c) 2021 by the authors. Licensee MDPI, Basel, Switzerland. This article is an open access article distributed under the terms and conditions of the Creative Commons Attribution (CC BY) license (https:// creativecommons.org/licenses/by/ $4.0 /)$.

\begin{abstract}
In this article, we demonstrate that contemporary financial reporting systems have the capacity to contribute significantly to the generation of innovation-relevant competitive intelligence. This potential arises because, as part of its regular work, the financial reporting system compiles, collects, analyzes, and synthesizes strategically relevant information about (i) complex internal technical processes related to inventions, discoveries, product development, process innovations, and the like; (ii) detailed sales, cost, and profit forecasts; (iii) consumer trends and innovative developments in the firm's markets; (iv) actual and potential competitor actions in the market; and (v) regulatory changes, macro-economic trends, and information about the likely impact of government policies. We argue that this competitive intelligence can, if properly harnessed, lead to better informed discourses and decisions around innovation. Consequently, we highlight the potential-from both academic research and practical perspectives-of financial reporting as an enabler of innovation-relevant competitive intelligence embeddedness within firms.
\end{abstract}

Keywords: innovation; competitive intelligence; financial reporting; case examples

\section{Introduction}

It is difficult to overstate the crucial importance of innovation for organizations seeking to survive and thrive in the globally competitive business environment [1,2]. Today, innovation is increasingly seen as a multi-disciplinary activity and professionals from a variety of fields seek to contribute to debates and discussions around the emergence, development, revision, and abandonment of innovation-led strategies [3-5]. Although the accounting function in organizations is not commonly associated with innovation [6-11], Ries [7] has identified the potential of contemporary accounting systems to contribute to corporate innovation processes. Furthermore, there has been a recent upsurge in the degree of co-operation between accounting professionals and those organizational participants concerned with innovation [12]. A related development is the exponential growth in open innovation settings where "the boundaries between the firm and its environment have become more permeable" [13] (p. 1) so that innovation can "easily be transferred in and out between firms ... as well as between firms and creative consumers". Open innovation contexts represent a growing and vitally important aspect of economic and societal activity to which our work is directly relevant.

In this article, we seek to add a new dimension to the rather limited extant literature on the potential of accounting systems from an innovation standpoint by demonstrating how one aspect of the firm's accounting architecture-specifically, the financial reporting system - contributes to strategic discourses and discussions around innovation. Financial reporting is the firm's primary means of communicating relevant financial information to external parties, such as shareholders and debtholders [9] and, here, we demonstrate that contemporary financial reporting systems have the capacity to contribute significantly to the generation of competitive intelligence [14] with respect to firm-level and industry-level 
innovation activities. We argue that this competitive intelligence can, if properly harnessed, lead to better informed strategic discourses and decisions around innovation activities within organizations.

While our core premise-that a firm's financial reporting system has significant potential as a source of competitive intelligence in innovation contexts-may come as a surprise, what is not always well understood outside of those directly impacted is that there has been a sea of change in financial reporting in recent years [9]. In effect, the corporate governance [15] and compliance demands [16] on the financial reporting system have increased exponentially, and while this has undoubtedly led to greater complexity and higher compliance costs, one very significant upside to these new demands is that firms' financial reporting systems are now required to collect a wide range of additional information about internal and external activities. Consequently, as a direct result of the new demands placed on the discipline, we argue here that financial reporting systems have now evolved into a potentially crucial source of competitive intelligence in the realm of innovation.

The remainder of our paper is structured as follows. In Section 2, we explain the key conceptual foundations of our article. In Section 3, we draw on cases to elaborate upon five specific elements of the financial reporting system which lead to the creation of innovation-relevant competitive intelligence within organizations. In Section 4, we present an overarching synthesis of financial reporting-based competitive intelligence modelling. Our final section summarizes and concludes.

\section{Conceptual Foundations}

In this section, we first elaborate on the concepts of 'competitive intelligence' and, relatedly, 'competitive intelligence embeddedness'. We then outline some relevant insights with respect to the financial reporting landscape before proceeding to identify the specific boundaries of our article and the core methodological framework.

\subsection{Competitive Intelligence}

Competitive intelligence is defined as a process which transforms "competitor, industry and market-data into actionable strategic knowledge about the competitor's capabilities, intentions, performance and position" [17] (p. 13). There are four commonly recognized elements to the competitive intelligence cycle $[18,19]$. The first- the planning phaseidentifies the intelligence needs of decision makers, while the second phase focuses on the collection of information about competitors. The third phase centers around the ways in which the raw data collected is transformed into actionable competitive intelligence, whilst the fourth phase refers to the communication of the competitive intelligence to C-level decision makers. Prior studies have shown that competitive intelligence with respect to the innovation activities of competitors is a vital component of a firm's quest to maximize long-term shareholder value [3-5,20].

Markovich et al. [18] (p. 2) furthermore highlight the crucial importance of competitive intelligence embeddedness, which they define as "the extent to which competitive intelligence permeates the entire organization so that strategic and tactical decisions can be made in the knowledge of all relevant external, competitive, information".

Gilad [21] (p. 1) suggests that "[s]imply and clearly put, competitive intelligence is a perspective on changing market conditions. This means identifying risks and opportunities early enough to allow the company to adapt its strategy or in extreme cases, change it." He suggests that that definition of competitive intelligence "forcefully delineates it from all other information, data, and research services". Crucially, [21] (p. 1) suggests that "information alone is not a perspective on change-information does not automatically lead to insight". Although, as the author emphasizes, this point is not always well understood by companies and executives. Gilad [21] also highlights the need for an integrated organizational approach towards generating and analyzing competitive intelligence. 


\subsection{Financial Reporting}

Weetman [10] (p. 153) explains that "financial reporting refers to a combination of quantitative accounting statements and narrative reports" directed at shareholders, lenders, and other stakeholders. Since the early part of the 21st century, a global accounting initiative that had already made slow but steady progress for several years began to gain serious momentum $[9,11,22,23]$. The aim of this initiative was (and is) the standardization of financial reporting practices globally. Today, more than 115 countries have signed up to international accounting standards (also termed 'international financial reporting standards'). One major exception is the US. There, regulators have decided to retain their own domestic accounting standards, known as US 'Generally Accepted Accounting Principles' (hereafter US GAAP), for the foreseeable future. International standards and US GAAP are similar in many respects, but there are several significant differences that we highlight at the appropriate junctures in our article.

Prior work in accounting calls for accounting researchers to contribute more to other disciplines $[8,24,25]$ and to become "more innovative" [8] (p. 851). Building on these calls, the present work extends the long-established field of financial intelligence $[9,26]$ and competitive financial intelligence $[9,26-28]$ by focusing on the ways in which financial reporting systems can contribute to the development of innovation-relevant competitive intelligence.

\subsection{Scope}

In this article, we focus exclusively on intangible assets, i.e., assets such as patents, trade names, trademarks, and copyrights. This is because financial reporting for intangible assets provides the most fertile ground for demonstrating the potential of the financial reporting system as a source of competitive intelligence from an innovation standpoint [12]. Due to space constraints, we do not address the extent to which 'creative accounting' [29-32] impacts on the role of financial reporting in competitive intelligence contexts. In addition, our article also does not explicitly consider the interaction between the external and internal accounting systems (i.e., management accounting systems) in competitive intelligence contexts [33].

\subsection{Methodological Framework}

Scholars in the fields of both accounting and innovation can draw upon decades of insightful research findings to develop new insights and paradigms. However, research at the interface of accounting and innovation is still a developing field with little in the way of extant literature. Prior literature in the innovation field [34] (p. 8) notes that "[w]hen a scientific field still needs more exploration and interpretation and is still little explored, with a substantial shortage of preliminary research on it, exploratory case studies are recommended". Case studies are a highly effective research methodology, and we build on prior insights to present contemporary case examples which illuminate the core ideas underlying our arguments. These contemporary case examples provide important 'realworld' illustrations which demonstrate - in both conceptual and practical terms-how financial reporting can make an important contribution across diverse industries as a source of innovation-relevant competitive intelligence.

\section{Contemporary Case Examples of Financial Reporting as a Source of Innovation-Relevant Competitive Intelligence}

In this section of the paper, we explain how innovation-relevant competitive intelligence emerges from the financial reporting system by focusing on five separate aspects of reporting for intangible assets. In each sub-section, we draw on contemporary case examples from the corporate world to illustrate our core arguments.

One important technical point to note at the outset of our discussion is that, when a firm buys an intangible asset, the purchased intangible is recorded as an asset on the firm's 'Statement of Financial Position' (i.e., Balance Sheet); in other words, the cost of the intangible is 'capitalized' [35]. Thereafter, a portion of the cost is written off as an expense 
on the firm's income statement (i.e., Profit and Loss account) over each period of the asset's useful life (a process called 'amortization'). If there is no perceived limit to the asset's useful life (i.e., if it has an unlimited useful life, such as a long-established brand), no amortization takes place. This is an important consideration, because, if the intangible asset remains on the balance sheet at its full original cost, then the reported financial position of the company is strengthened. This would also have a positive impact on reported profits because none of the original cost would be charged as an expense. We elaborate on these-and other relevant concepts-in more detail later.

\subsection{Research and Development}

The first area to which we turn our attention is that of accounting for research and development (R\&D) activities. As we explained above, when a firm buys an intangible asset, it is capitalized and added to other assets on the balance sheet. What though of the financial reporting system's approach to dealing with the firm's expenditure on R\&D efforts to develop an intangible asset 'in-house'?

Under international accounting rules, accountants are required to capitalize that component of R\&D expenditure which they deem likely to bring measurable future benefits. In contrast, the remaining component of R\&D expenditure-that which is not deemed to have clearly visible long-term benefits-is "expensed" (i.e., treated as an expense on the firm's income statement). Reported profits will be reduced by the amount written off as an expense. With reference to the question of whether or not to capitalize R\&D expenditures, the accounting rules specify that the object of the development process must be both technically feasible and economically viable (in the sense that the development under consideration is potentially profitable). Since the decision about whether to capitalize R\&D expenditure is complex, the firm's financial reporting system needs to gather substantial internal technical intelligence about the product, process, or service being developed. In addition, the firm needs to be aware of the market potential of the specific innovation under consideration. This requires a detailed study of, for example, the likelihood of regulatory approval (where appropriate) and the sales and profit potential if the product is approved, as well as detailed analysis of the current activities and likely reactions of both existing and potential competitors.

\section{Contemporary Case Examples}

Accounting for R\&D provides innovation-relevant competitive intelligence in two ways. First, the decision to expense or capitalize requires detailed analysis of internal and external data. For example, in 2016, Smiths Group plc capitalized GBP 25 million in development costs to bring its total capitalized development costs to date to GBP 302 million. Smiths Group states in its 2016 annual report [36] (p. 140) that it capitalizes "expenditure incurred in respect of the development of major new products where the outcome of those projects is assessed as being reasonably certain as regards viability and technical feasibility." Clearly, this assessment req3.uires the compilation of detailed internal and external intelligence with respect to the technical and commercial aspects of the developments under review. This means that the financial reporting function must also analyze and interpret substantial amounts of commercially sensitive data.

Second, firms can gain significant market knowledge by monitoring when their competitors capitalize development expenditures, as this is a direct signal that the competitor has developed something new and innovative that it expects to be a success in the marketplace. For example, in its 2016 annual report, Philips AG [37] (p. 133) explains that it capitalized EUR 318 million of product development construction in progress. By capitalizing this sum, Philips AG is signaling that its R\&D work is yielding outcomes that are likely to translate into measurable future economic benefits. This is a strong and confident signal to external parties that its R\&D efforts are paying off. The company also expensed over EUR 2 billion of research costs in its 2016 income statement. This expenditure-although it is not capitalized-may eventually bring substantial future benefits. However, the com- 
pany has chosen not to classify the work underlying this expenditure as an asset, as it does not meet the criteria discussed earlier.

\subsection{Software Development}

With international accounting standards, expenditure on software development is treated in the same way as any other type of development expenditure (as per our previous discussion). However, software development highlights one major difference between US GAAP and international accounting. In contrast to the international accounting practice, US GAAP prohibits the capitalization of development expenditure, except for one specific activity: software development.

Consequently, in a similar manner to the way non-US firms assess their R\&D expenditures, firms reporting under US GAAP must establish the technical feasibility and economic viability of any software that is currently being developed. This means that the financial reporting function must gather significant intelligence about these aspects of the work being undertaken by its own internal software development professionals and marketing personnel. In addition, the financial reporting system requires reliable estimates of how the software being developed will perform in the marketplace. Therefore, the financial reporting system needs to gather significant intelligence about the innovation activities of competitors as well as overall market-level changes and trends.

\section{Contemporary Case Examples}

According to its 2016 annual report, Aspen Technology Inc. [38] (p. F.16) capitalizes software development costs "upon establishing technological feasibility defined as meeting specifications determined by the program design." This detailed assessment is ultimately the responsibility of the financial reporting function in conjunction with experts in the field. The stakes are high for a company like Aspen Technology Inc., as it has, up to the end of fiscal year 2015, capitalized and subsequently amortized software development costs totaling \$73.8 million. Relatedly, Nestlé reported total internally generated capitalized development expenditures of 742 million Swiss francs. The company explains in its 2016 annual report [39] (p. 88) that most of this represents management information systems software that is capitalized, as it will be "useful in generating future benefits in terms of savings, economies of scale, etc." Again, quantifying these savings and economies of scale requires in-depth data collection, which can ultimately lead to the generation of substantial competitive intelligence about technical and market innovations.

Detailed analysis of the ways in which peer group firms are accounting for their software development expenditures can also provide useful competitive intelligence with respect to innovation. For example, in its 2015 annual report [40], Blackbaud Inc. reported a $\$ 7.2$ million increase in capitalized software development costs. The company states (p. 46) that, "the increase in the amount capitalized was a result of incurring more qualifying costs associated with development activities." It also points out (p. 46) that "[w]e expect that the increase in the amount of software development costs capitalized will continue in the near-term as we make investments on innovation, quality and the integration of our solutions which we believe will drive revenue growth." This is a strong signal to external parties, not least the competitor firms, that the firm's investment in innovation activities is both substantial and valuable-otherwise capitalization would not have taken place. Consequently, as with accounting for R\&D, analysis of accounting for software development costs can lead to the generation of innovation-relevant competitive intelligence through the synthesis of the firm's own internal knowledge base in conjunction with the analysis of the reports of competitors.

\subsection{Impairment Testing}

In recent years, firms have been required to implement a relatively new process called "impairment testing" with respect to each of their intangible assets. The purpose of this process is to estimate the amount, if any, of the reduction in value of the intangible assets. 
To explain this process, let us assume that an intangible asset is being held on the balance sheet at an amount (called the "carrying amount") of \$10 million. The financial reporting system must determine whether that asset is still worth $\$ 10$ million at the fiscal year end. To do this, the system generates a number called the "recoverable amount" of the asset. This figure is calculated as the higher of two independently estimated numbers: the current market value of the asset (less any selling costs) and the "value in use" of the asset. The market value of the asset is usually easily available for regularly traded intangible assets. In contrast, the value-in-use figure represents an estimate of what the asset is worth to the business from an internal perspective and is calculated as the discounted future net cash flows from the asset.

Suppose in our example that the market value of the intangible asset after deducting selling costs was $\$ 7$ million, while the value in use was $\$ 5$ million; the higher of those figures, $\$ 7$ million, is deemed to be the recoverable amount. As the asset is being carried on the balance sheet at $\$ 10$ million and its recoverable amount is just $\$ 7$ million, the firm will have to write off an impairment loss of $\$ 3$ million to the income statement.

To estimate the fair value of each asset, firms must compile or acquire detailed and up-to-date market values. This information is often provided by external valuation experts. However, it is in determining the value in use of the asset that the most competitive intelligence with respect to market-level and firm-level innovations is generated. For example, the financial reporting system must collect detailed information about the likely future cash inflows and cash outflows from the asset and apply the appropriate opportunity cost of capital discount rates to make realistic estimates of the value in use. In turn, this process requires detailed estimates about, for example, the future cash flows of the business, likely competitor actions, and future industry wide developments. While the financial reporting system cannot-and is not expected to-accurately predict the future, the calculations made should be a realistic reflection of the best available information at a given time. Furthermore, firms are required to disclose the most important inputs to their estimation models.

\section{Contemporary Case Examples}

The impairment testing process leads to the development of potentially useful sources of innovation-relevant competitive intelligence in several ways. First, firms must bring together the best inside knowledge from other functional areas in order to establish realistic estimates of recoverable amounts. For example, in their 2016 annual report [41] (p. 185), Novartis points out that the impairment testing requires inputs about the "the amount and timing of projected future cash flows; outcome of R\&D activities (compound efficacy, results of clinical trials, etc.)." Furthermore, the financial reporting system at Novartis needs to take cognizance of the amount and timing of costs to achieve commercial viability, estimates of the probability of achieving regulatory approval, long-term sales forecasts "for periods of up to 20 years," future taxation projections, and cost of capital estimates. Finally, it needs to consider how quickly sales will erode when patent protection expires, and it also should evaluate the "behavior of competitors (launch of competing products, marketing initiatives, etc.)." Overall, then, given that Novartis must undertake the impairment testing process for all intangible assets at least annually (and more often if dramatic changes in market conditions occur), a considerable amount of potentially crucial information-most of which is relevant to innovation-based organizational discourses-must be gathered by the firm on a regular basis.

Second, by scanning the impairment testing reports of other firms in the industry, firms can glean important insights into the current and future innovations and actions of their direct competitors. Adidas, in its 2015 annual report [42] (p. 210), revealed that the risk-adjusted weighted average cost of capital for its internal estimates of the recoverable amount of one of its trademarks ranges between $6.8 \%$ and $8.4 \%$. While Adidas finds no evidence for impairment of that particular intangible asset class in 2015, it also reveals that an increase of up to $1 \%$ in the discount rate or a decrease in future cash inflow projections 
of up to $13 \%$ would result in an impairment loss. Similarly, Samsung's annual report [43] provides important information about its impairment testing process in 2015 (p. 112). Its average annual sales growth estimates were only $1 \%$, while the opportunity cost of capital that it used to discount future cash flows was 9.5\%. Although these figures represent conservative estimates on Samsung's part, they convey useful information about industrylevel innovation projections around technology, markets and customers.

Finally, it is worthwhile noting that under international accounting standards (although not under US GAAP), firms can reverse impairment losses if the grounds for the original impairment decision have changed. For example, on page 42 of its 2015 annual report, Evotec [44] explains that, in 2014, it reversed prior impairment losses in the amount of EUR 6.4 million with respect to one of its compounds, EVT 401, "following advanced discussions with an undisclosed partner to extend an existing licensing agreement to include also all rights for the lead compound EVT 401 except for the Chinese market." Such disclosures provide important information about relevant commercial innovations.

\subsection{Business Combinations}

Under both international accounting standards and US GAAP, when one firm takes over another, the acquiring firm is required to separately measure-in as much detail as possible - the individual assets and liabilities of the acquired company. For example, suppose Company $\mathrm{X}$ paid $\$ 10$ million cash to acquire Company $\mathrm{Y}$. Assume also that the market value of the total assets less total liabilities (i.e., the net assets) of Company $Y$ at the date of the deal was just $\$ 4$ million. The difference between these figures (i.e., $\$ 6$ million) will be recorded as a separate asset on Company $X^{\prime}$ s balance sheet under the title of "goodwill." Goodwill is a "catch all" category that captures aspects of Company Y's value not reflected in its individual assets, as well as the component of the price paid by Company $\mathrm{X}$ attributable to predicted synergies from the deal. Goodwill is typically a large component of the assets acquired in most contemporary business combinations.

\section{Contemporary Case Examples}

Accounting for business combinations leads to the generation of innovation-relevant competitive intelligence in several ways. First, the size of the goodwill created reveals the expectation of the acquiring firm with respect to the synergies it forecasts from the deal and the expected sources of those synergies. For example, in its 2016 annual report, AstraZenca [45] (p. 175) explains that it acquired BMS's share of Global Diabetes Alliance Assets. AstraZenca paid $\$ 2703$ million, and $\$ 1530$ of this amount (i.e., approximately $60 \%$ ) was attributable to the goodwill component. AstraZenca further explains (p. 175) that "goodwill of $\$ 1530$ million arising on the transaction is underpinned by a number of elements which individually cannot be quantified." It adds that the most significant of these "are the synergies AstraZenca expects to be able to generate though more efficient manufacturing processes and the incremental value accessible through strategic and operational independence upon taking full control of the alliance." Once again, these types of disclosures provide important insights into the importance of manufacturing innovations as well as the synergies emerging from other expected innovations.

Second, marketing executives frequently complain that although brand-building expenditures, such as advertising, are essential to the long-term success of the business, these expenditures are usually treated as expenses rather than assets on firms' financial statements. However, when firms buy another business, they are required to capitalize the separately identifiable assets_-including marketing assets — of the firm being acquired. Therefore, for instance, if the separately identifiable assets of the acquired firm include a marketing asset, such as a brand name, then the value of that brand must be recognized on the acquirer's balance sheet. Consequently, in order to calculate the value and useful life of the brand, the financial reporting system of the acquiring firm will have to engage in detailed internal and external analysis of new innovations in the customer- market, competitor actions, and the firm's own innovations with respect to its products. 
For example, in its 2015 financial report, Pfizer [46] (p. 130) explains that it includes more than $\$ 8$ billion in brand values on its balance sheet (comprised of $\$ 1.044$ billion in brands with a limited life and $\$ 7.021$ billion in brands with an unlimited life). These values are included because of prior takeover and acquisition deals. In accounting for these brands, Pfizer's financial reporting system must estimate the useful life of the brands, their market value, and their value in use. Clearly then, financial reporting with respect to the brand values recorded as part of business combinations leads to the generation of significant innovation-relevant competitive intelligence.

\subsection{Goodwill Impairment}

Goodwill is usually the largest component of the intangible assets recorded on firms' balance sheets. Under both international accounting standards and US GAAP, goodwill is not subject to any regular write-off (i.e., amortization), as it is considered to have an indefinite life. However, as with all other intangible assets, goodwill is subject to an annual impairment review based on the impairment testing procedures described earlier. Once impaired, however, there can be no recovery of impairment losses for goodwill under either international accounting standards or US GAAP.

\section{Contemporary Case Examples}

First, the work by the financial reporting system on goodwill impairment requires the synthesis and analysis of considerable amounts of innovation-relevant internal and external data. For example, in its 2015 annual report [47] (p. 119), Vodafone Group plc explains that the key assumptions underlying its estimates of the recoverable amounts of the goodwill for its various divisions are as follows (with the figures for the German division in parentheses): pre-tax adjusted discount rate $(8.2 \%)$, long-term growth rate $(0.5 \%)$, and growth in budgeted capital expenditure (expressed as between $11.6 \%$ and $21.7 \%$ of annual sales revenue). After working through the relevant calculations in 2014, Vodafone Group plc wrote off GBP 4900 million to its income statement in goodwill impairment charges for its German division.

Second, goodwill impairment can provide important signals about trends in innovation within individual industry sectors. For example, in early 2017, Pearson plc announced a write-off of goodwill amounting to GBP 2.548 billion. In its 2017 press release pertaining to the announcement of its fiscal 2016 results, Pearson plc explained (p. 16) that "at the end of 2016 it became clear that the underlying issues in the North American higher education courseware market were more severe than anticipated." It further explained that "these issues related to declining student enrolments, changes in buying patterns of students and correction of inventory levels by distributors and bookstores." This was subsequent to previous significant goodwill write-offs in 2015 of GBP 507 million attributable (p. 16) to "significant economic and market deterioration in the Group's operations in emerging markets and ongoing cyclical and policy related pressures in the Group's mature market operations." Clearly, as firms must carry out the impairment testing process on goodwill at least annually (and more often if deemed necessary as a result of market-level innovations), firms compile substantial amounts of innovation-relevant competitive intelligence on a regular basis.

\section{An Overarching Synthesis of Financial Reporting-Based Competitive Intelligence Modelling}

The case studies presented in the previous section show that, as part of its regular work, the financial reporting system compiles, collects, analyzes, and synthesizes strategically relevant information about (i) complex internal technical processes related to inventions, discoveries, product development, process innovations, and the like; (ii) detailed sales, cost, and profit forecasts; (iii) consumer trends and innovative developments in the firm's markets; (iv) actual and potential competitor actions in the market; and (v) regulatory changes, macro-economic trends, and information about the likely impact of government policies. Although the financial reporting system engages in these tasks to ensure that the 
firm's external reports are accurate and fair, this work simultaneously leads to the compilation of a significant competitive intelligence knowledge base that is directly relevant to discourses and decisions centered around innovation. Consequently, we demonstrate that financial reporting has significant-albeit frequently untapped-potential as a generator of competitive intelligence with respect to firm-level and industry-level trends in innovation.

Relatedly, we note that, within open innovation contexts, the role of big data analysis is of crucial and ever-growing importance. Financial reporting systems have always employed data analysis techniques of varying degrees of sophistication. However, the emergence of the science of big data has dramatically altered the scale and scope of data analysis possibilities. Today, big data techniques are rapidly becoming a central part of the ways in which financial reporting data is utilized and this trend has clear ramifications for financial reporting-based competitive intelligence modelling. Relatedly, we note that big data analyses can be significantly augmented through the application of the Extensible Business Reporting Language (XBRL). As XBRL allows for the compilation of a wide range of financial reporting data from public information sources [48], XBRL is particularly important from the perspective of applying the concepts presented here in open innovation contexts.

\section{Conclusions}

\subsection{Implications}

In this article, we seek to add a new dimension to literature at the intersection of competitive intelligence and innovation by demonstrating how a frequently overlooked aspect of the firm's information systems-specifically, the financial reporting system-has the potential to contribute innovation-relevant competitive intelligence. We show that the regular day-to-day business of the contemporary financial reporting function requires the collection, synthesis, and analysis_-from both internal and external sources—of vast amounts of data, which, in turn, provides a potentially vital source of competitive intelligence with respect to firm-level and industry-level innovations. In this way, the financial reporting system can augment the process of competitiveness intelligence embeddedness with respect to organizational discourses surrounding innovation in its broadest sense.

\subsection{Financial Reporting within Open Innovation Networks}

The myriad of new developments in financial reporting practices which we discuss here have, in many ways, taken the discipline to the forefront of competitive intelligence generation. Contemporaneous cross-functional developments in customer analytics, XBRL and the science of big data only serve to enhance the considerable potential that already exists. The overarching outcome of these development is that financial reporting now has significant-albeit frequently untapped-potential as a generator of competitive intelligence with respect to innovation with a particular focus on open innovation.

Within this network, financial reporting could benefit from the application of ideas centered around the concept of 'collective intelligence' [49]. As discussed earlier, financial reporting functions across individual firms gather significant quantities of actionable competitive intelligence with respect to innovation. Whilst firms understandably wish to utilize their competitive intelligence in a 'selfish' manner, there is also potential for firms to contribute to collective intelligence [49] (p. 1) "as a means of solving problems through exchange and cooperation, with groups that are both internal and external to them". In this way, firms can, for example, contribute to solutions to industry wide concerns, such as industry impacts on the natural environment [22,23,32]. Relatedly, the financial reporting discipline can itself benefit from collective intelligence in dealing with well-established professional quandaries, such as the appropriate treatment of advertising expenditures [9]. In fact, in relatively innovative fields within the financial reporting space-such as those related to cryptocurrency [50] and decentralized finance ("DeFi") [51]—collective intelligence is likely to be a prerequisite for resolving issues related to decentralized autonomous organization (DAO) accounting. 
Open innovation networks are likely to prove to be vital conduits for ensuring that collective intelligence in financial reporting contexts is optimized. In this sense, financial reporting functions within organizations can contribute to open innovation networks and can simultaneously benefit from the emergence of such networks. Consequently, by engaging with open innovation collective intelligence networks, financial reporting systems can contribute in more symbiotic ways to innovation-relevant competitive intelligence. Relatedly, the future education pathways for professionals in the accounting and financial reporting spaces likely need to give greater weight to open innovation paradigms associated with the emergence of the 4th industrial revolution (4IR).

\subsection{Future Research}

Future research at the intersection of financial reporting and competitive intelligence needs to take cognizance of the potential influence of information overload as [21] (p. 1) "[i]n recent years with the big data craze, collecting digital data has replaced strategic intelligence". Nonetheless, [21] (p. 1) firms "waste millions on massive databases or research projects that do not yield useful insight" and tend to push consideration of competitive intelligence to the "tactical product level, missing out on the true value of competitive intelligence as a purveyor of strategic change". Consequently, the challenge for professionals in the field is to avoid contributing to the proliferation of data at the organizational level and to focus on competitive intelligence which makes a real contribution to strategic change.

Future work in the field also needs to take cognizance of alternative conceptualizations of business strategy. For example, Carton [52] (p. 4) explains that the blue ocean strategy "aims at breaking with the logic of the competitive strategy" so that "boundaries and industry structures are not given and can be reconstructed based on the actions and beliefs of industry players". Our work shows that intelligence derived from the financial reporting system can support the development of blue ocean strategy analytical frameworks. In this sense, we believe that financial reporting can make an important contribution as a source of innovation-relevant competitive intelligence within both blue ocean strategic frameworks as well as more traditional strategic paradigms.

Equally well, financial reporting has the potential to contribute from a strategic intelligence perspective in the context of the emerging "digital economy of ecosystems" [53] (p. 1) in which "competition is eliminated, and organizations form unions and alliances in order to work together and cooperate to reach a set goal". Given the growing importance of digital ecosystems in contemporary business and societal contexts, the role of accounting systems as a source of business intelligence within such ecosystems is likely to become a dominant theme in the development of research at the interface of financial reporting and strategy. Our work demonstrates that financial reporting also has the potential to contribute valuable intelligence in the context of strategic environments focused on cooperation as well as competition [54-57].

The role of financial reporting in the context of industries and settings where cooperation is a fundamental requirement is likely to become more important given the recent proliferation of such ecosystems (both digital and otherwise) [53]. For example, Gilad [21] (p. 1) observes that "popular literature is filled with definitions and images of competitive intelligence taken from the realm of the government and the military" so that the field becomes focused "on competitors ("the enemy" in military parlance) instead of the market as a whole-the entire competitive arena". Taken in conjunction with the broader concept of blue ocean strategy [52] and the proliferation of alliances [53], the message for researchers and practitioners at the interface of financial reporting and competitive intelligence is clear: work in this field needs to be fully cognizant of opportunities for financial reporting to contribute in a variety of non-traditional business strategies and within a wide range of organizational and industrial structures.

From a methodological standpoint, we encourage additional qualitative work incorporating case studies as well as interviews with experts and practitioners [26]. Quantitative 
work utilizing statistical analysis and econometric modelling $[11,15,58,59]$ can also make an important contribution to the field.

In conclusion, we believe that our work here will encourages academic researchers interested in cross-disciplinary research as well as senior executives to become more aware of the innovation-relevant competitive intelligence potential of contemporary financial reporting systems.

Author Contributions: Conceptualization, V.O.; literature review, V.O., N.A., G.W.; methodology, V.O.; formal analysis, V.O., N.A.; G.W.; supervision, N.A.; investigation, V.O., N.A., G.W.; resources, V.O., N.A., G.W.; writing—original draft preparation, V.O.; writing—review and editing, V.O., N.A., G.W. All authors have read and agreed to the published version of the manuscript.

Funding: This research received no external funding.

Data Availability Statement: Data sharing not applicable.

Conflicts of Interest: The authors declare no conflict of interest.

\section{References}

1. Johnson, M. Reinvent Your Business Model: How to Seize the White Space for Transformative Growth; Harvard Business Review Press: Boston, MA, USA, 2018.

2. Del-Corte-Lora, V.; Molina-Morales, F.; Vallet-Bellmunt, T. Mediating effect of creativity between breadth of knowledge and innovation. Technol. Anal. Strateg. Manag. 2016, 28, 768-782. [CrossRef]

3. Kim, H. How a firm's position in a whole network affects innovation performance. Technol. Anal. Strateg. Manag. 2019, 31, 155-168. [CrossRef]

4. McGrath, R. The End of Competitive Advantage: How to Keep Your Strategy Moving as Fast as Your Business; Harvard Business Review Press: Boston, MA, USA, 2018.

5. Thiel, P.; Masters, B. Zero to One: Notes on Start-Ups or How to Build the Future; Crown Publishing Group: New York, NY, USA, 2014.

6. Demirag, I. The impact of managers' short-term perceptions on technology management and R\&D in UK companies. Technol. Anal. Strateg. Manag. 1996, 8, 21-32.

7. Ries, E. The Lean Start-Up; Crown Publishing Group: New York, NY, USA, 2011.

8. Basu, S. How can accounting researchers become more innovative? Account. Horiz. 2012, 26, 851-870. [CrossRef]

9. Revsine, L.; Collins, D.; Johnson, B.; Mittelstaedt, F.; Soffer, L. Financial Reporting and Analysis, 8th ed.; McGraw-Hill: New York, NY, USA, 2021.

10. Weetman, P. Financial Reporting in Europe: Prospects for research. Eur. Manag. J. 2018, 36, 153-160. [CrossRef]

11. Whelan, G.; Hanly, P.; O'Connell, V.; Dittrich, O.L.; Abu Ghazalah, N. Impact on Firm Liquidity Arising from Outsourcing Decisions as Evidenced by Off-Balance-Sheet Disclosures. Int. Adv. Econ. Res. 2021. [CrossRef]

12. Tysiac, K. How Finance and Accounting Can Boost Innovation. Available online: https://www.journalofaccountancy.com/news/ 2013/sep/20138692.html (accessed on 5 December 2020).

13. Baboshkin, P.; Yegina, N.; Zemskova, E.; Stepanova, D.; Yuksel, S. Non-Classical Approach to Identifying Groups of Countries Based on Open Innovation Indicators. J. Open Innov. Technol. Mark. Complex. 2021, 7, 77. [CrossRef]

14. Fu, L.; Liu, Z.; Zhou, Z. Can open innovation improve firm performance? An investigation of financial information in the biopharmaceutical industry. Technol. Anal. Strateg. Manag. 2018, 31, 776-790. [CrossRef]

15. O'Connell, V. Dealing with panel data in accounting and managerial finance research. Int. J. Manag. Financ. 2007, 3, 372-389. [CrossRef]

16. Abu Ghazalah, N.; O'Connell, V.; Princen, J. Audit quality, auditor size and legal environments. Q. J. Financ. Account. 2015, 53, 39-78.

17. Bernhardt, D. I want it fast, factual, actionable-Tailoring competitive intelligence to executives' needs. Long Range Plan. 1994, 27, 12-24. [CrossRef]

18. Markovich, A.; Efrat, K.; Raban, D.; Souchon, A. Competitive intelligence embeddedness: Drivers and performance consequences. Eur. Manag. J. 2019, 37, 708-718. [CrossRef]

19. Nasri, W. Competitive intelligence in Tunisian companies. J. Enterp. Inf. Manag. 2011, 24, 53-67. [CrossRef]

20. Ardito, L.; Petruzzelli, M. Breadth of external knowledge sourcing and product innovation: The moderating role of strategic human resource practices. Eur. Manag. J. 2017, 35, 261-272. [CrossRef]

21. Gilad, B. Competitive intelligence shouldn't just be about your competitors. Harv. Bus. Rev. 2015, 5, 1.

22. Murphy, T.; O'Connell, V.; O'Hógartaigh, C. Discourses surrounding the evolution of the IASB/FASB Conceptual Framework: What they reveal about the "living law" of accounting. Account. Organ. Soc. 2013, 38, 72-91. [CrossRef]

23. Murphy, T.; O'Connell, V. Challenging the dominance of formalism in accounting education: An analysis of the potential of stewardship in light of the evolution of legal education. Crit. Perspect. Account. 2017, 44, 1-29. [CrossRef] 
24. Ngwakwe, C. Dilemmas in accounting research and implication for management. Corp. Ownersh. Control 2014, 11, 214-222. [CrossRef]

25. Sanchez-Matamoros, J.B.; Gutiérrez-Hidalgo, F.; Macías, M. Innovation in accounting thought and practice-An introduction. Account. Hist. 2015, 20, 247-249. [CrossRef]

26. Cascino, S.; Clatworthy, M.; Garcia Osma, B.; Gassen, J.; Imam, S. The usefulness of financial accounting information: Evidence from the field. Account. Rev. 2021. [CrossRef]

27. Calof, J.; Sewdass, N. On the relationship between competitive intelligence and innovation. J. Intell. Stud. Bus. 2020, 10, 32-43. [CrossRef]

28. Calof, J.; Richards, G.; Santilli, P. Insight through open intelligence. J. Intell. Stud. Bus. 2017, 7, 62-73.

29. Serrano-Cinca, C.; Gutierrez-Nieto, B.; Bernate-Valbuena, M. The use of accounting anomalies indicators to predict business failure. Eur. Manag. J. 2019, 37, 353-375. [CrossRef]

30. O'Connell, V. The information content of security prices on the Irish Stock Exchange. Br. Account. Rev. 1995, 27, 311-324. [CrossRef]

31. O'Connell, V.; O'Sullivan, D. The impact of customer satisfaction on CEO bonuses. J. Acad. Mark. Sci. 2011, 39, 828-845. [CrossRef]

32. O'Connell, V. Reflections on stewardship reporting. Account. Horiz. 2007, 21, 215-227. [CrossRef]

33. Langfield-Smith, K. Strategic management accounting: How far have we come in 25 years? Account. Audit. Account. J. 2008, 21, 204-228. [CrossRef]

34. Silva, R.; Coelho, A.; Sousa, N.; Quesado, P. Family Business Management: A Case Study in the Portuguese Footwear Industry. J. Open Innov. Technol. Mark. Complex. 2021, 7, 55. [CrossRef]

35. O'Connell, V.N.A.; Kintou, A. The impact of R\&D programme success on the decision to capitalise development expenditures in European firms. Technol. Anal. Strateg. Manag. 2018, 30, 15-30.

36. Smiths.com. Results, Reports and Presentations. Available online: https://www.smiths.com/investors/results-reports-andpresentations (accessed on 1 December 2020).

37. Philips. 2016 Annual Results. Available online: https://www.results.philips.com/publications/ar16 (accessed on 20 December 2020).

38. Aspen. Annual Reports. Available online: http://ir.aspentech.com/annual-reports (accessed on 24 November 2020).

39. Nestle. Annual Report. Available online: https://www.nestle.com/media/mediaeventscalendar/allevents/2016-annual-report (accessed on 1 August 2020).

40. Blackbaud. Annual Reports. Available online: http://phx.corporate-ir.net/phoenix.zhtml?c=176673\&p=irol-reports (accessed on 1 March 2020).

41. Novartis. Annual Report. Available online: https://www.novartis.com/sites/www.novartis.com/files/novartis-annual-report2016-en.pdf (accessed on 22 August 2020).

42. Adidas. Financial Reports. Available online: https://www.adidas-group.com/en/investors/financial-reports/2015/ (accessed on 21 April 2021).

43. Samsung. Annual Business Report. Available online: https://images.samsung.com/is/content/samsung/p5/global/ir/docs/ 2015_business_quarter04.pdf (accessed on 20 December 2020).

44. Evotec. Financial Reports. Available online: https://www.evotec.com/f/01a18775a8003b73c90888039cec103c.pdf (accessed on 22 September 2020).

45. AstraZeneca. Annual Report. Available online: https://www.astrazeneca.com/investor-relations/annual-reports/annualreport-2016.html (accessed on 27 October 2020).

46. Pfizer. Annual Report. Available online: https://www.pfizer.com/sites/default/files/investors/financial_reports/annual_ reports/2016/index.html (accessed on 20 September 2020).

47. Vodafone. Annual Report. Available online: https://www.annualreports.com/HostedData/AnnualReportArchive/v/LSE_ VOD_2015.pdf (accessed on 27 February 2020).

48. Schuster, P.; O'Connell, V. The trend toward voluntary corporate disclosures. Manag. Account. Q. $2006,7,1$.

49. Lee, J.-Y.; Jin, C.-H. How Collective Intelligence Fosters Incremental Innovation. J. Open Innov. Technol. Mark. Complex. 2019, 5, 53. [CrossRef]

50. Mikhaylov, A. Cryptocurrency Market Analysis from the Open Innovation Perspective. J. Open Innov. Technol. Mark. Complex. 2020, 6, 197. [CrossRef]

51. Knab, M. DAO Accounting. DeFi Accounting Series. Available online: https://defiprime.com/dao-accounting (accessed on 1 April 2019).

52. Carton, G. How Assemblages Change When Theories Become Performative: The case of the Blue Ocean Strategy. Organ. Stud. 2020, 41, 1417-1439. [CrossRef]

53. Barykin, S.Y.; Kapustina, I.V.; Kirillova, T.V.; Yadykin, V.K.; Konnikov, Y.A. Economics of Digital Ecosystems. J. Open Innov. Technol. Mark. Complex. 2020, 6, 124. [CrossRef]

54. O'Connell, V.; O'Sullivan, D. The influence of lead indicator strength on the use of nonfinancial measures in performance management: Evidence from CEO compensation schemes. Strateg. Manag. J. 2014, 35, 826-844. [CrossRef]

55. O'Connell, V.; Lee, J.; O'Sullivan, D. The influence of CEO equity incentives on licensing. Eur. Manag. J. 2018, 36, 266-277. [CrossRef] 
56. O'Connell, V.; Lee, J.H.; O'Sullivan, D. Taking stock of corporate risk-taking. MITSloan Manag. Rev. 2018, 60, 15.

57. O'Connell, V.; O'Sullivan, D. Are nonfinancial metrics good leading indicators of future financial performance? MITSloan Manag. Rev. 2016, 57, 21-23.

58. Whelan, G.; Sarmiento, R.; Sprenger, J. Universal-deterministic and probabilistic hypotheses in operations management research: A discussion paper. Prod. Plan. Control 2018, 29, 1306-1320. [CrossRef]

59. AbuGhazaleh, N.M.; Al-Hares, O.M.; Roberts, C. Accounting Discretion in Goodwill Impairments: UK Evidence. J. Int. Financ. Manag. Account. 2011, 22, 165-204. [CrossRef] 